\title{
TRABALHO E CONVÍVIO SOCIAL: A REPRESENTAÇÃO DA VIVÊNCIA DO TEMPO PELA SOCIEDADE CAPITALISTA NO CURTA- METRAGEM EL EMPLEO
}

\begin{abstract}
ADRIANA CARNEIRO MARINHO ${ }^{1}$
Resumo: O presente ensaio tem por finalidade uma análise do curta-metragem El Empleo (2008), de Patricio Plaza e Santigo Bou Grasso, partindo das perspectivas da temática do tempo imprimidas ao longo da trama. Com efeito, são explorados os elementos oferecidos pelo filme que nos remetem à questão do tempo do trabalho intrínseco ao modo de produção capitalista e suas ramificações na esfera cotidiana. Para tanto, parto de uma bi bliografia pertinente às relaçóes entre o tempo e o trabalho na modernidade, com destaque para a temática da reificação. Destarte, evidencia-se que o filme de Santiago Bou Grasso propicia uma relevante contribuição ao estudo do tempo e à identificação de suas manifestações na arte.
\end{abstract}

Palavras-chave: Cinema; Reificação; Tempo; Trabalho.

El Empleo (O Emprego) é um curta-metragem de animação produzido em 2008 pelo diretor argentino Santiago Bou Grasso, a partir do roteiro de Patricio Plaza, também argentino $^{2}$. Executada pelo estúdio "Opus Bou”, foi uma produção independente aclamada nacional e internacionalmente - tendo sido contemplada com mais de cem prêmios e indicaçóes em festivais de cinema, tais como Mar del Plata Film Festival, Annecy International Animated Film Festival, Hiroshima International Animation Festival, São Paulo International Short

1 Graduanda em História pela Universidade São Paulo - USP e membro do GMarx - Grupo de Estudos de História e Economia Política da FFLCH - USP.

adriana.marinho@usp.br

2 O filme conta com pouco mais de seis minutos e pode ser acessado em: http://www.opusbou.com.ar/ e https://www.youtube.com/watch?v=cxUuU1jwMgM. 
Trabalho e convívio social: a representação da vivência do tempo pela sociedade capitalista no curta-metragem El empleo

Film Festival. A animação foi feita com base em 8.600 desenhos feitos à mão, por isso levou dois anos para ser finalizada.

Nessa produção audiovisual de animação, a diegese trata da rotina de um trabalhador comum, desde a sua dificuldade em despertar e se preparar para mais uma jornada, até a sua chegada ao local de trabalho. Os realizadores do filme transformaram pessoas em objetos de cena, como móveis, luminárias, espelhos e até mesmo automóveis (ver imagens dispostas ao longo do artigo). Após despertar, o protagonista faz a barba e toma café antes de sair de casa. Para chegar ao trabalho, pega um táxi - no caso, um ser humano que cumpre o papel de um automóvel. Ao longo desse contexto, aparecem pessoas, objetificadas ou não, com as quais o protagonista interage apenas de maneira mecânica - não há diálogos e as personagens parecem nem se dar conta da presença umas das outras.

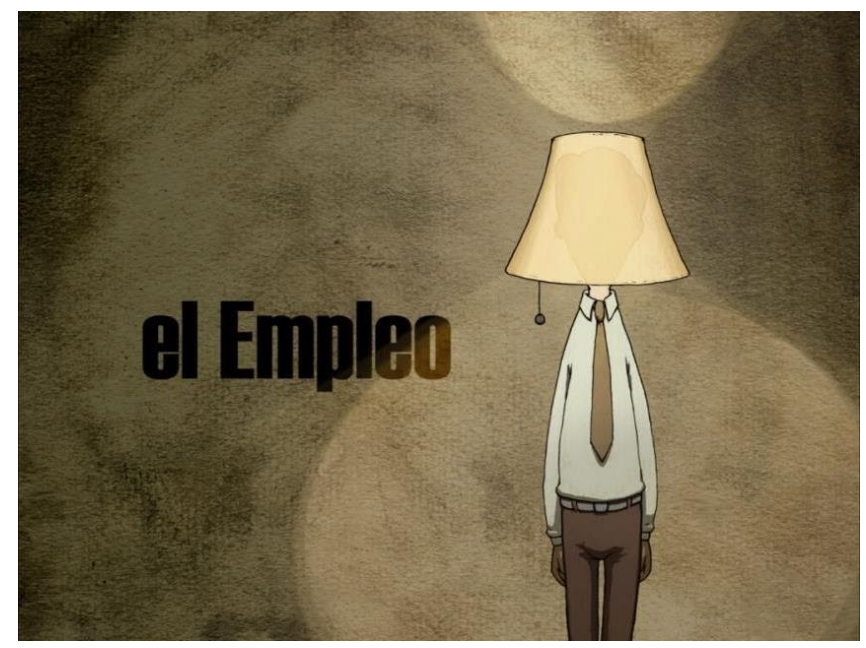

Imagem 1: Pôster (BOU GRASSO, 2008). 


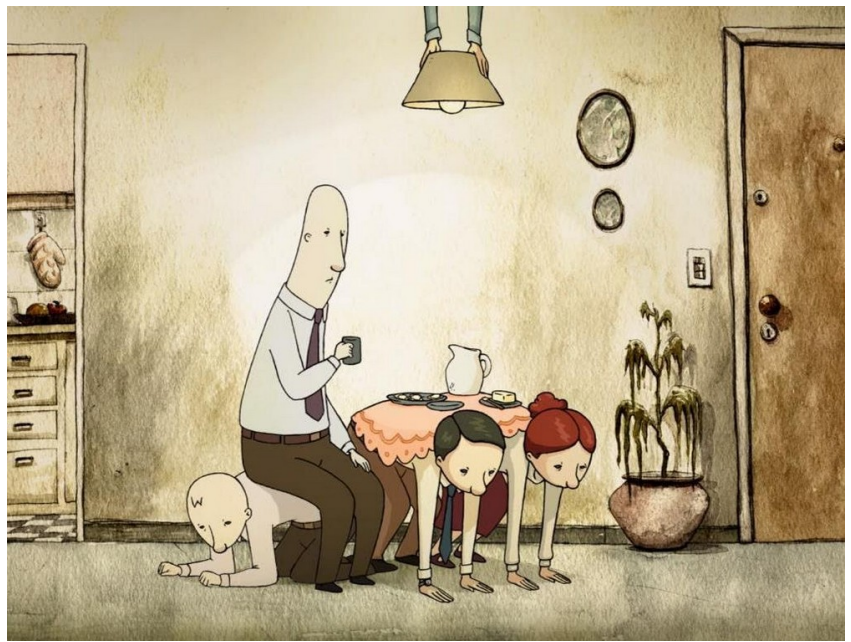

Imagem 2: Cena - café da manhã (BOU GRASSO, 2008).

Conforme já sinalizado, pretende-se aqui uma reflexão acerca do curta-metragem tendo em vista a temática do tempo de maneira mais ampla e, mais especificamente, do tempo referente ao trabalho no sistema capitalista - abordagens que, como veremos, cruzam-se na medida em que o tempo do trabalho se impõe sobre a vida cotidiana de maneira geral. A princípio, faz-se necessária uma justificativa mais apurada do objetivo aqui proposto, haja vista que, ao tratar da tônica do trabalho na sociedade contemporânea, o curta direciona os holofotes muito mais para a exploração e reificação do trabalhador do que para a questão do tempo do trabalho propriamente dito.

Ao admitirmos o método de Karl Marx, temos que o valor da força de trabalho enquanto mercadoria - é determinado pelo tempo de trabalho demandado por sua produção (MARX, 1996, p. 345). Se considerarmos ainda que a reificação é resultado das relações sociais de produção capitalistas, bem como das condições através das quais se dá a exploração da força de trabalho, podemos assumir que há uma relação intrínseca entre o tempo de trabalho no capitalismo e a reificação. Em El Empleo, a trama baseada na rotina diária de um trabalhador, aliada à desumanização das personagens - inclusive do próprio protagonista - expressa claramente essa relação.

Considerando o fato de que o filme não fala sobre um contexto espaço-temporal preciso, prescinde-se de uma análise que tenha em conta as particularidades históricas dessa 
Trabalho e convívio social: a representação da vivência do tempo pela sociedade capitalista no curta-metragem El empleo

construção teórica marxista, o que não elimina a responsabilidade de apontar que, muito embora o capital tenha caráter universal, seus atributos estruturais não se manifestaram e nem se manifestam de maneira homogênea e idêntica em todas as épocas e lugares onde imperou, ou impera, o sistema capitalista. Sendo assim, a construção argumentativa adotada nesse texto se atentará ao debate sobretudo teórico e generalista desse modo de produção, a partir de uma interpretação que procure uma relação coerente com as possibilidades embutidas no curtametragem.

Ademais, muito embora o tempo não nos salte aos olhos como o elemento central do filme - já que muitas vezes está relacionado a objetos mais concretos, tais como o reló gio, que aparece na trama apenas duas vezes -, uma observação mais atenta revela que muitas de suas faces permeiam toda a sequência do curta-metragem de Bou Grasso como, por exemplo, a ideia de rotina ou repetição, a sensação de tédio, ou mesmo o modo lento como se dão os acontecimentos.

No primeiro livro d'O Capital, Marx desenvolve o conceito de fetichismo, entendido como um fenômeno decorrente da forma mercadoria, predominante no modo de produção capitalista, em que as coisas se personificam e as pessoas se objetificam. Com efeito, o autor demonstra como as coisas se movem como pessoas e as pessoas como coisas, na medida em que os seres humanos passam a ser dominados pelas próprias mercadorias que produzem (MARX, 1996, p. 197-208).

Na primeira metade do século XX, visando uma revolução comunista de fato, diferente do reformismo cada vez mais acentuado nos partidos social-democratas da Europa Ocidental, Georg Lukács escreve História e Consciência de Classe (2003). Em uma perspectiva dialética, o autor se preocupa em teorizar as bases através das quais se desenvolve a consciência do sujeito no capitalismo, identificando as possibilidades - dentro de condições tanto objetivas, quanto subjetivas - do proletariado se apropriar de uma consciência crítica e subverter a ordem capitalista.

Nesse contexto, na esteira do fetichismo de Marx, Lukács propóe o conceito de reificação, que diz respeito ao outro lado da moeda do fetiche da mercadoria - focado no sujeito, o autor se preocupa com o processo em que o ser humano é objetificado, ou seja, reifica do (LUKÁCS, 2003, p. 193-412). Adota-se, nesse artigo, o conceito de Lukács por considerálo mais preciso - a despeito dos dois constituírem uma relação dialética, em que a separação se dá apenas para fins analíticos - uma vez que, no filme aqui analisado, não são os objetos (mer - 
cadorias) que ganham vida, mas as pessoas que aparecem objetificadas, cumprindo funções de seres inanimados.

Se estamos falando de uma dada maneira de viver e conceber o tempo, convém explicitar o contexto no qual se dá essa inversão, haja vista o processo de ascensão do capitalismo e as novas demandas sociais. Em Costumes em Comum (1998), Edward Thompson trata dessa transformação, que se dá de maneira mais aprofundada sobretudo a partir do século XVII, explicitando o tempo do relógio em contraposição ao tempo da natureza prevalecente outrora (THOMPSON, 1998, p. 267-271). O relógio indica, nesse sentido, uma disciplina e uma necessidade de controle do tempo. Oportunamente, o filme aqui tratado inicia-se justamente com a revelação de um relógio (imagem 3), que serve também como despertador do personagem principal. Tem-se aqui, indubitavelmente, a representação do tempo do trabalho se impondo em relação ao tempo da natureza, bem como a outros tempos biológicos, isso é reforçado pelo semblante de sonolência do personagem principal ao despertar - característica essa que se manterá por todo o filme.

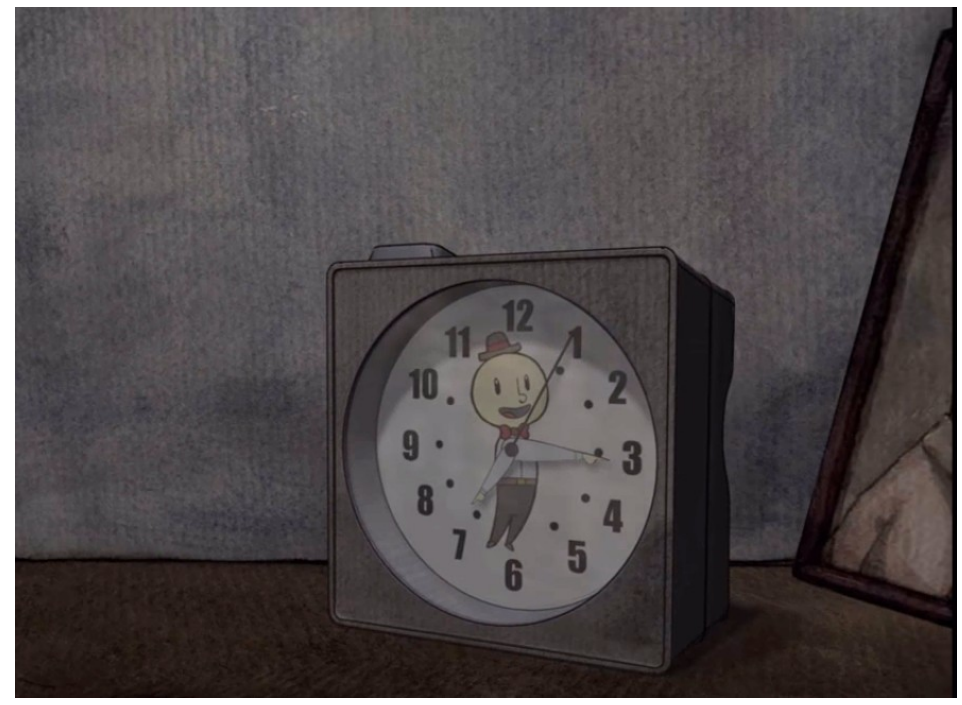

Imagem 3: Cena - relógio despertador (BOU GRASSO, 2008).

Em meio à mescla de sons advindos de movimentos corporais e manipulação de objetos, além de uma poluição sonora distante, com os ecos de um vazio existencial, o barulho insistente do despertador que dá início à trama talvez seja o som mais vívido do curta e um dos mais simbólicos frente ao objetivo de análise aqui proposto. A segunda aparição de um relógio, embora mais tímida e imediata, é também passível de significados nesse sentido. Em seu caminho ao trabalho, quando no "táxi” (imagem 5), nosso protagonista lança uma olhadela 
Trabalho e convívio social: a representação da vivência do tempo pela sociedade capitalista no curta-metragem El empleo

ao seu relógio de pulso. Essa ação ligeira é ainda acompanhada de um som cuja carga simbólica é bastante notável - os passos acelerados das pessoas que representam os táxis exprimem a ideia de pressa e rapidez que caracterizam fortemente o tempo do trabalho e a vivência do tempo nos mais variados âmbitos da vida na sociedade capitalista.

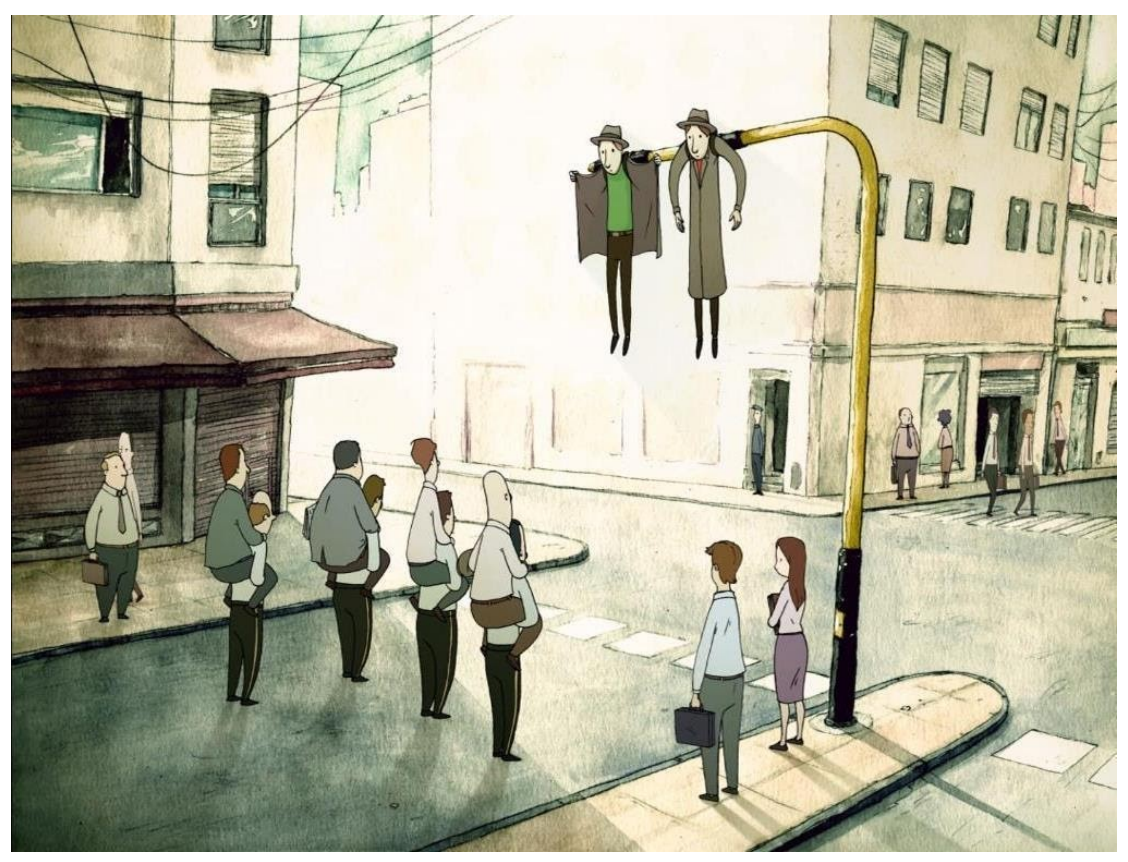

Imagem 4: Cena - semáforo (BOU GRASSO, 2008).

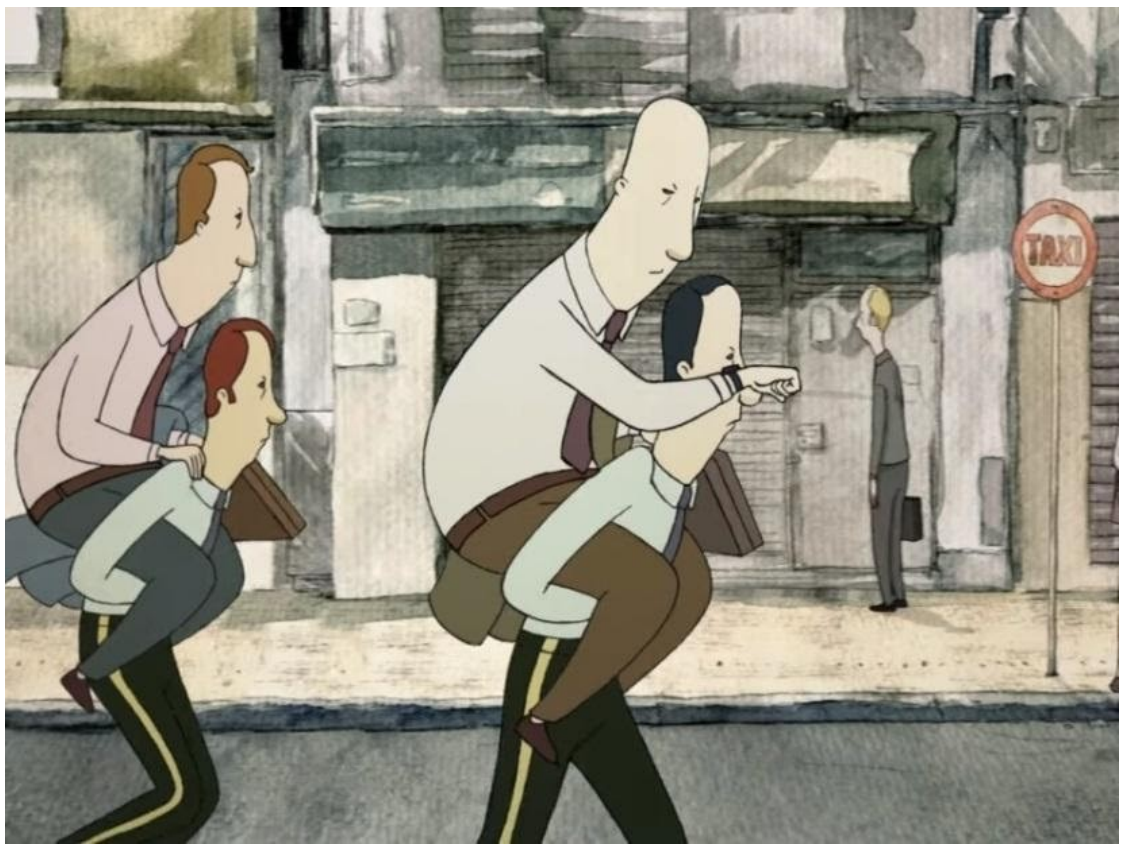


Imagem 5: Cena - relógio de pulso (BOU GRASSO, 2008).

A forma determinada de vivência e percepção do tempo pela sociedade retratada no filme é ainda corroborada pela própria recepção deste pelo público - nesse sentido, são valiosas as informações que encontramos no vídeo postado pela Opus Bou no YouTube. Com mais de seis milhôes de visualizações e pouco mais de dois mil comentários, percebe-se um tom geral de identificação das pessoas com a ideia de exploração proposta no curta. A maioria critica o capitalismo e a sociedade em que vivem.

Não obstante, alguns discordam que o filme representa uma reprovação ao trabalho e enfatizam a importância do capitalismo para a evolução da sociedade - enquanto ou tros, naturalmente, externam que não entenderam nada. O essencial, todavia, é que parece fazer sentido a ideia de que qualquer ser humano hoje inserido na economia-mundo determinada pelo modo de produção capitalista, se identifique, de maneira ou de outra, com o contexto geral, as formas e os costumes estampados no filme de Bou Grasso. Esses padróes podem ser evidenciados na formação urbana e arquitetônica da cidade, nos objetos domésticos e no modo como são manuseados, ou ainda na maneira de se vestir (imagens 2 e 4).

A identificação por parte de tal espectador se dá ainda, certamente, e mesmo que inconscientemente, no que diz respeito à vivência do tempo - tempo este universalizado, na medida em que se dá a acumulação capitalista ao longo dos séculos e a globalização que a acompanha. Assim, não fossem os elementos metafóricos utilizados para simbolizar a objetificação dos seres humanos, a rotina do protagonista - acordar com o despertador, tomar café e ir ao trabalho - seria como que uma mera reprodução cinematográfica da vida desse espectador.

Em se tratando da expressão da reificação, ou seja, da forma como as pessoas são retratadas no curta - como vimos, objetificadas - condição decorrente das relações de trabalho às quais são submetidas, o relógio despertador aparece novamente como um primeiro indício. Há a representação de um homem no centro, cujos braços servem como os ponteiros das horas e minutos (ver imagem 3). Até então, num primeiro momento, nada chocante ou esdrúxulo, tendo em vista que não se trata de um homem "em carne e osso". Contudo, assim que o nosso protagonista acorda e acende a lâmpada do abajur, vemos uma pessoa propriamente dita ali objetificada (imagem 1), dando início a uma sequência de pessoas nas mesmas condições (de objeto) que vão passando ao longo das diferentes situações nos seis minutos do filme. 
Trabalho e convívio social: a representação da vivência do tempo pela sociedade capitalista no curta-metragem El empleo

Conforme comentado, a reificação está relacionada intimamente com a questão do tempo do trabalho, uma vez que são as relações sociais da produção e especialmente a exploração da força de trabalho - que, por sua vez, pressupóe o tempo de trabalho como seu va lor - os fatores condicionantes desse fenômeno. Sobre isso, é elucidativa a forma como Marx inicia o capítulo sobre a jornada de trabalho no vol. 1 d'O Capital:

\footnotetext{
Partimos do pressuposto de que a força de trabalho seja comprada e vendida pelo seu valor. Seu valor, como o de qualquer outra mercadoria, é determinado pelo tempo de trabalho necessário à sua produção. Se, portanto, a produção dos meios de subsistência médios diários do trabalhador exige 6 horas, então ele precisa trabalhar 6 horas por dia para produzir diariamente sua força de trabalho ou para reproduzir o valor recebido por sua venda. A parte necessária de sua jornada de trabalho compreende então 6 horas e é, portanto, mantendo-se inalteradas as demais circunstâncias, uma grandeza dada. Mas com isso não é dada a grandeza da própria jornada de trabalho. (MARX, 1996, p. 345). ${ }^{3}$
}

Assim, Marx demonstra como o tempo de trabalho necessário é determinante para a constituição do valor da força de trabalho. Da mesma forma, mais adiante, o autor ainda mostra que o tempo é também determinante na criação da mais-valia, já que esta advém do tempo de trabalho excedente na jornada de trabalho. Se essa é a uma relação essencial na caracterização do modo de produção capitalista, em termos objetivos, são observados correspondentes também no âmbito da subjetividade - Lukács aponta para importância de entendermos a sociedade capitalista a partir de uma totalidade concreta, composta por fatores infra e superestruturais, uma relação dialética em que não há a imposição de quaisquer desses fatores sobre todos os outros, como queria o marxismo vulgar (LUKÁCS, 2003, p. 63-104).

Com efeito, as condiçóes objetivas da produção de mercadorias expostas por Marx encontram reflexo na alienação e na reificação do sujeito. Há em El Empleo a representação dessa relação dialética: da mesma forma em que se vê a objetificação das personagens ao longo de toda a narrativa, tudo no filme caminha para o momento em que o protagonista exerce seu papel de proletário e imediatamente é reificado, através do recurso metafórico - sua função no trabalho é servir de tapete, sobre o qual o seu superior pisa.

3 Não é dada aí a grandeza da jornada de trabalho, pois, como sabemos, nesta implica ainda o problema da mais-valia, cuja taxa é determinada pela razão entre o tempo de trabalho excedente e o tempo de trabalho necessário, isto é, a fração do tempo de trabalho exigida para a produção dos meios de subsistência do trabalhador. 
Ainda sobre as implicações decorrentes da associação entre a reificação e o tempo no modo de produção capitalista, o intelectual húngaro István Mészáros, na sua disposição em destrinchar a tirania do imperativo do tempo do capital, caindo na redução dos seres humanos ao que chama de "carcaça do tempo", oferece-nos uma sistematização teórica referente a essas questôes, que pode ser de grande contribuição à linha argumentativa aqui proposta:

\footnotetext{
Um dos aspectos mais degradantes da ordem social do capital é que reduz os seres humanos à condição reificada, a fim de adequá-los aos estreitos limites da contabilidade do tempo do sistema: o único gênero de contabilidade - extremamente desumanizadora - compatível com a ordem social do capital. Esse tipo de desenvolvimento social tão humanamente empobrecedor é justificado teoricamente na forma de uma abstração ideologicamente reveladora operada pelos economistas políticos que vinculam de forma direta a individualidade abstrata (os indivíduos isolados) e a universalidade abstrata (a vigente divisão e fragmentação capitalista do trabalho decretada como regra universal atemporal criada pela própria natureza). (MÉSZÁROS, 2007, p. 42).
}

O modo com que estamos inclinados a viver o tempo, explicitado de maneiras diversas no curta El Empleo, surge, portanto, das condiçôes e relaçôes sociais que se transformam e se estabelecem com o desenvolvimento do modo de produção capitalista, ao mesmo tempo que as reproduz constante e repetidamente no decorrer dos séculos. Nesse processo, a contabilidade do tempo do sistema, como nos mostra Mészáros, cumpre uma função desumanizadora.

Ainda nesse sentido, cabe mencionar a diferenciação feita por Thompson entre a notação de tempo outrora realizada pelas tarefas domésticas em regiões rurais e o tempo disciplinado e controlado referente ao relógio e o horário marcado. O autor conclui que o primeiro é mais bumanamente compreensivel e que nele há pouco distanciamento entre o "trabalho" e a "vida", ao contrário do que ocorre, evidentemente, no processo em que se dá o segundo. (THOMPSON, 1998, p. 271). 
Trabalho e convívio social: a representação da vivência do tempo pela sociedade capitalista no curta-metragem El empleo

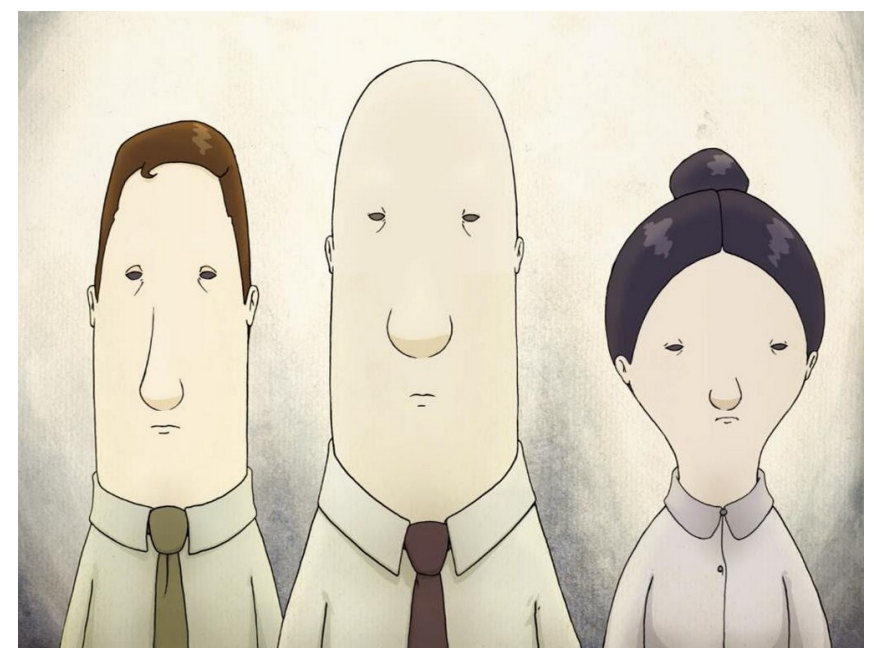

Imagem 6: Cena - expressóes faciais (BOU GRASSO, 2008).

Para além da objetificação do ser humano expressa no filme de maneira crua e visceral, a reificação pode ainda ser observada nas expressóes faciais das pessoas ali representadas. O único sorriso que vemos durante todo o filme é, ironicamente, o do desenho do homem es tampado no relógio - podendo ser interpretado, inclusive, como uma manifestação do fetiche da mercadoria, um dos lados do mesmo processo dialético no qual se configura a reificação. $\mathrm{O}$ relógio é, assim, o único elemento que carrega um sentimento humano: a felicidade. Ademais, as faces são todas inexpressivas, nem felizes nem tristes, consideravelmente desumanizadas (imagem 6). As pessoas se vestem de maneira extremamente parecidas, conforme o visual formal de trabalho no mundo ocidental, agem de modo robótico e não conversam nem interagem entre si. 


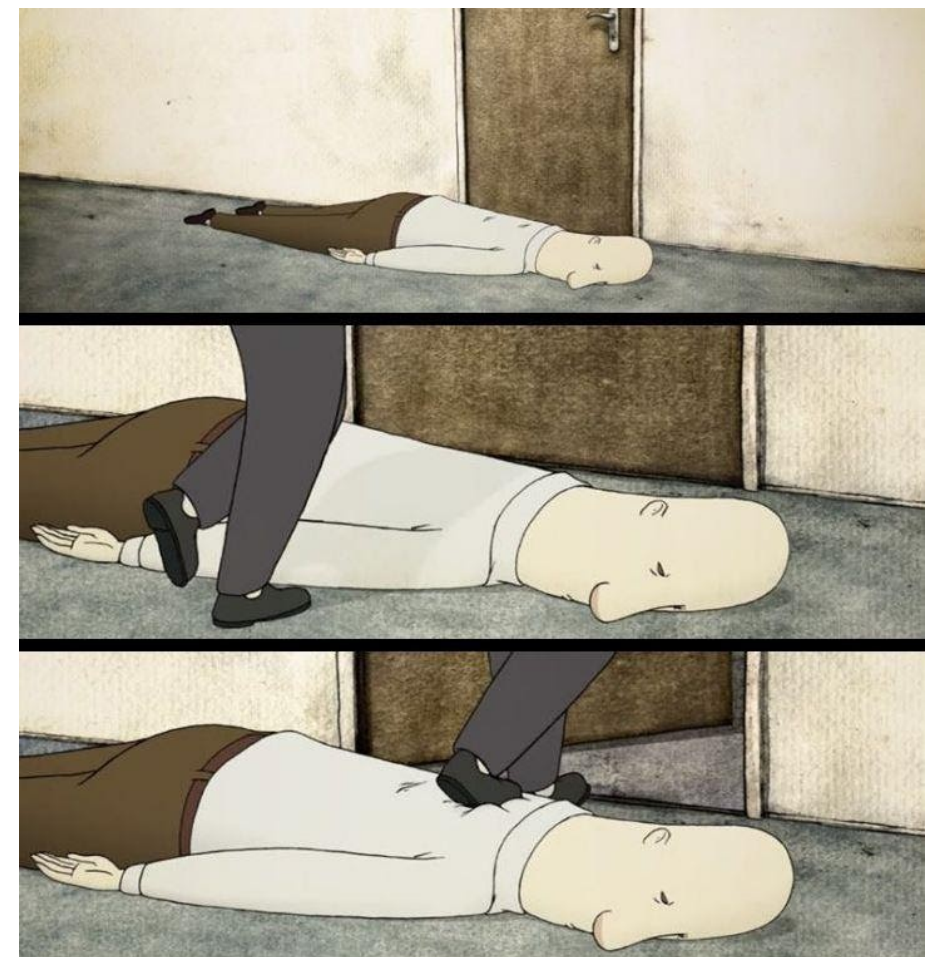

Imagem 7: Cena - objetificação do protagonista (BOU GRASSO, 2008).

Concluo essa análise apontando para um possível ponto de inversão no final do curta, que se relaciona ainda com o que vemos posteriormente, nos créditos. Ao chegar ao seu local de trabalho e servir de tapete para o patrão pisar, o personagem central da trama, após al guns segundos característicos do ritmo "arrastado" que permeia o filme, lança um suspiro profundo, revelando um traço de humanidade. Chegando finalmente aos créditos, a personagem objetificada no abajur se livra dessa condição, arrancando-o de seu corpo e atirando-o ao chão (imagem 8). No que tange a isso, a partir do raciocínio interpretativo aqui exposto, temos uma possibilidade ao ser humano de libertar-se da reificação, ao que mais uma vez encontramos correspondente teórico em Mészáros:

[...] Entretanto, o tempo livre da humanidade não é uma noção especulativa, mas uma potencialidade muito real e, por sua própria natureza, inexaurível. Existe como o tempo disponível virtualmente ilimitado - porque generosamente renovável e ampliável - dos indivíduos sociais, capaz de ser colocado em uso criativo por eles como indivíduos auto-realizadores, contanto que os propósitos significativos a 
Trabalho e convívio social: a representação da vivência do tempo pela sociedade capitalista no curta-metragem El empleo

que suas ações servem emerjam de suas próprias deliberações autônomas. Essa é a única maneira de transformar os potenciais emancipatórios da humanidade na realidade libertadora da vida cotidiana. (MÉSZÁROS, 2007, p. 63).

O autor defende, portanto, que a possibilidade de libertação da humanidade, frente ao capitalismo e às condiçôes degradantes que o acompanham, é algo inerente à liberdade do tempo e do tempo livre, bem como à criatividade e autonomia dos indivíduos. Nesse sentido, tendo em conta a construção interpretativa do filme proposta nesse artigo, a cena final e a cena pós-créditos exprimem essa tentativa de libertação, em que mais uma vez, naturalmente, o tempo é elemento fundamental. Assim, se é através do tempo (nas condições específicas tratadas) que se dá a desumanização das personagens retratadas no filme, a libertação dessa condição sugere claramente uma atitude em relação a ele, bem como a instituição de um outro modo de vivê-lo - por conseguinte, no que diz respeito a isso, o tempo livre nos termos colocados por Mészáros se mostra bastante oportuno.

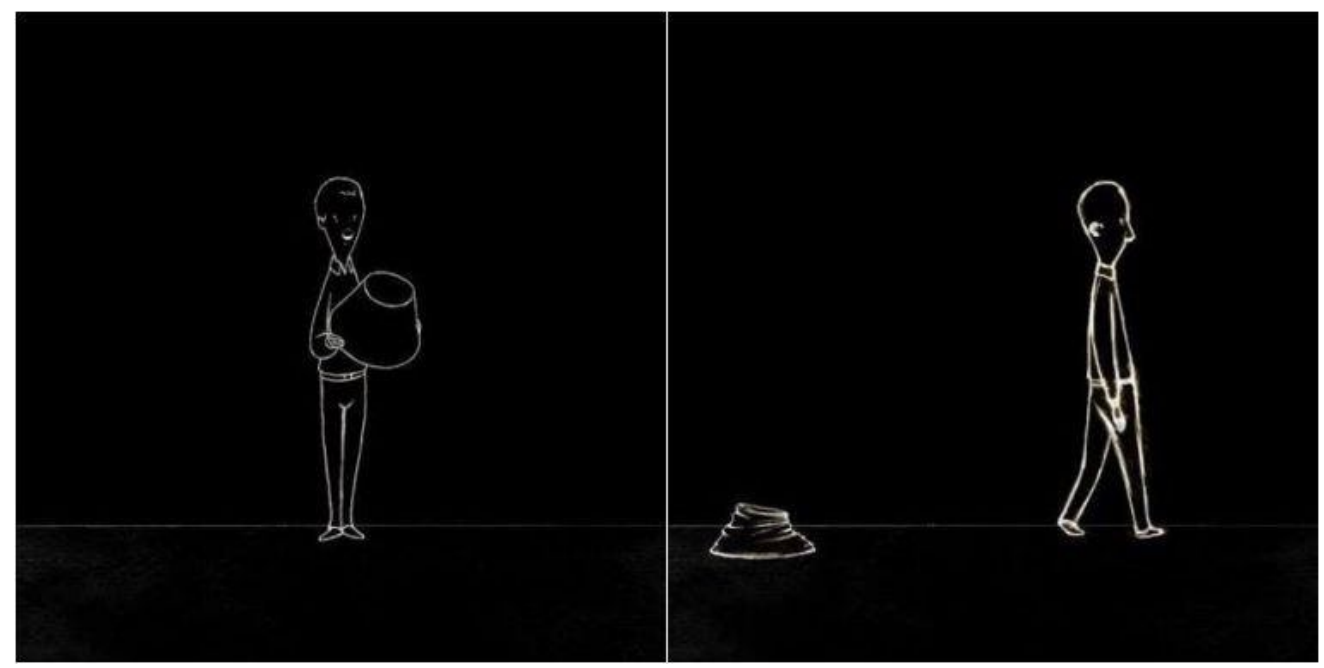

Imagem 8: Cena - tomada de consciência (BOU GRASSO, 2008).

Destarte, evidencia-se que, muito embora alguém possa afirmar que o tempo não está em discussão ou não é o elemento central do filme, suas faces se revelam ao longo de toda a narrativa e é possível percebê-las, conscientemente - como talvez aconteça quando vemos os relógios - ou de maneira mais velada, expressa em sua relação com o tempo do trabalho no capitalismo e a reificação decorrente das relações sociais engendradas por esse sistema econômico; no modo enfadonho com que se passam os seis minutos da trama; ou ainda na clara ideia de rotina e repetição, decorrente da mecanização dos movimentos das personagens. 


\section{REFERÊNCIAS BIBLIOGRÁFICAS}

BRAUDEL, F. A Dinâmica do Capitalismo. Tradução de Álvaro Cabral. Rio de Janeiro: Rocco, 1987.

EL EMPLEO. Produção de Patricio Plaza e Santiago Bou Grasso. Opus Bou, Buenos Aires, 2008, 6 min. Disponível em: http://www.opusbou.com.ar/ e https://www.youtube.com/ watch?v=cxUuU1jwMgM. Acesso em 15/10/2018.

EL EMPLEO - 100 Film Festival and Contests Awards. Opus Bou. Disponível em: http:// www.opusbou.com.ar/. Acesso em: 09 Jan. 2018.

LUKÁCS, G. História e Consciência de Classe: estudos sobre a dialética marxista. São Paulo: Martins Fontes, 2003.

MARX, K. O Capital. São Paulo: Editora Nova Cultural, vol.1, 1996.

MÉSZÁROS, I. O desafio e o fardo do tempo histórico: o socialismo no século XXI. São Paulo: Boitempo, 2007.

POSTONE, M. Tempo, trabalbo e dominação social: uma reinterpretação da teoria crítica de Marx. São Paulo: Boitempo, 2014.

THOMPSON, E. P. Costumes em comum. São Paulo: Companhia das Letras, 1998.

\section{IMAGENS}

Imagem 1: Pôster (BOU GRASSO, 2008).

Imagem 2: Cena - café da manhã (BOU GRASSO, 2008).

Imagem 3: Cena - relógio despertador (BOU GRASSO, 2008).

Imagem 4: Cena - semáforo (BOU GRASSO, 2008).

Imagem 5: Cena - relógio de pulso (BOU GRASSO, 2008).

Imagem 6: Cena - expressões faciais (BOU GRASSO, 2008). 
Trabalho e convívio social: a representação da vivência do tempo pela sociedade capitalista no curta-metragem El empleo

Imagem 7: Cena - objetificação do protagonista (BOU GRASSO, 2008).

Imagem 8: Cena - tomada de consciência (BOU GRASSO, 2008).

Todas as imagens foram reproduzidas por meio de print screen do filme de Bou Grasso, disponibilizado pelo seu estúdio, Opus Bou, em: http://www.opusbou.com.ar/ e https:// www.youtube.com/watch? $=\mathrm{cxUuU} 1 \mathrm{jwMgM}$. 